\begin{tabular}{|l|l|l||}
\hline \multicolumn{2}{|c|}{ PublisherInfo } \\
\hline \hline PublisherName & $:$ & BioMed Central \\
\hline \hline PublisherLocation & $:$ & London \\
\hline \hline PublisherImprintName & $:$ & BioMed Central \\
\hline \hline
\end{tabular}

\title{
Prenatal origins of human intrapulmonary arteries formation and smooth muscle maturation
}

\begin{tabular}{|l|l|l||}
\hline \multicolumn{2}{|c|}{ ArticleInfo } \\
\hline \hline ArticleID & $:$ & 1647 \\
\hline \hline ArticleDOI & $:$ & $10.1186 /$ rr-2001-68579 \\
\hline \hline ArticleCitationID & $:$ & 68579 \\
\hline \hline ArticleSequenceNumber & $:$ & 58 \\
\hline \hline ArticleCategory & $:$ & Paper Report \\
\hline \hline ArticleFirstPage & $:$ & 1 \\
\hline \hline ArticleLastPage & $:$ & 4 \\
\hline \hline & & RegistrationDate : 2001-9-19 \\
\hline ArticleHistory & $:$ & Received \\
\hline ArticleCopyright & $:$ & Biomed Central Ltd2001 \\
\hline \hline ArticleGrants & $:$ & \\
\hline \hline ArticleContext & $:$ & 129312211 \\
\hline \hline
\end{tabular}


Susan Schachtner, ${ }^{\text {Affl }}$

Corresponding Affiliation: Aff1

Aff1 Children's Hospital of Philadelphia, USA

\section{Keywords}

Development, lung, pulmonary artery, smooth muscle cell, vasculogenesis

\section{Introduction}

There is a paucity of information on mechansims of lung vessel development. In the past many studies focused on dye injections or casts to draw conclusions about vessel formation. Recently more investigators have used molecular markers to evaluate differentiation, maturation and vessel formation. This paper gives the most complete description of smooth muscle development in the pulmonary vasculature to date.

\section{Comments}

This paper contributes new information on the origins of pulmonary arterial smooth muscle during human prenatal development. It provides a very good description of patterns of contractile protein expression during smooth muscle development and maturation. In particular, several differences in the program of maturation between bronchial and arterial smooth muscle were found. The authors conclude that pulmonary artery smooth muscle cells originate from three sources; however, since static points are evaluated in this study this is a difficult hypothesis to prove. The paper adds additional support to the generally accepted theory of vasculogenesis as the mechanism of distal lung arterial development. No major comment is made on the development of the pulmonary veins.

\section{Methods}


Immunohistochemistry studies on fetuses aged 28 days to newborn with a three dimensional reconstruction from serial sections.

\title{
Results
}

Three successive origins of pulmonary arterial smooth muscle cells were described. The first source was smooth muscles cells surrounding the bronchi that sent out extensions toward nearby developing vessels and then eventually surrounded the vessel. These cells had a brick-like shape that persisted with maturation. The next layer of smooth muscle cells, that were fusiform in shape, differentiated from the mesenchyme surrounding the vessels. These cells initially did not stain for contractile proteins, but the proteins appeared with age. The third source of smooth muscle cells originated from cells in the lung mesenchyme that simultaneously stained for CD31, an endothelial cell marker, and alpha-smooth muscle actin.

The authors describe maturation of the vessel wall layers. The older, more proximal walls of airways and arteries matured first, with maturation of the smaller, newer structures occurring later in development. Maturation was compared by evaluation of alpha-smooth muscle actin, smooth muscle SM1, gamma-smooth muscle actin, calponin, caldesmon, and in the bronchial smooth muscle, desmin. Desmin was not seen at any time in the vascular smooth muscle cells.

\section{Discussion}

The authors state that the study provides evidence that the airways are essential for the development of the pulmonary arteries. From the study, they conclude the airways also contribute a portion of the vascular smooth muscle cells, and all pulmonary arterial smooth muscle cells from different origins express contractile proteins in the same sequence. They identify several factors that may be responsible for the epithelial-mesenchyme communication such as vascular endothelial growth factor, endothelin, transforming growth factor $\beta$, and platelet-derived growth factor.

\section{Additional information}

\author{
Additional references:
}

A related, complementary article was recently published by Millino C et al: Cardiac and smooth muscle cell contribution to the formation of the murine pulmonary veins.

Dev Dyn 2000, 218:414-425 


\section{References}

1. Hall SM, Hislop AA, Pierce CM, Haworth SG: Prenatal origins of human intrapulmonary arteries formation and smooth muscle maturation. Am J Resp Cell Mol Biol. 2000, 23: 194-203.

This PDF file was created after publication. 